\author{
Hanna Kędzierska \\ Uniwersytet Warmińsko-Mazurski w Olsztynie
}

\title{
Noty terenowe - status, przetwarzanie i potencjał badawczy
}

\author{
Fieldnotes - Status, Processing and Research Potential
}

Streszczenie. Specyfiką badań jakościowych jest praca z danymi pochodzącymi z różnych źródeł. Jednym z nich są sporządzane przez badaczy zapiski terenowe w postaci pamiętników, dzienników osobistych, instytucjonalnych, różnego rodzaju notatek z terenu badań. Prowadzone zgodnie $z$ bardzo zindywidualizowanymi regułami, nie są przygotowywane do przedstawiania zewnętrznemu czytelnikowi. Pomimo to znaczna ich część trafia w finale do raportu końcowego. W artykule, odwołując się do własnych doświadczeń badawczych, wskazuję rolę i potencjał badawczy tkwiący w zapisanych i przetworzonych notach terenowych.

Słowa kluczowe: nota terenowa; przetwarzanie not terenowych; badania jakościowe.

Summary. Qualitative research is specifically based on data gathered from various sources. One of such sources are fieldnotes recorded by researchers in the form of memoirs, personal diaries, institutional records, and various notes taken in the course of field research. Recorded according to very individual and personal criteria, fieldnotes are not designed to be presented to external readers. Nevertheless, a large proportion of such notes is included in the final research report. Based on my personal research experience, in this paper I discuss the role and research potential of recorded and then properly processed fieldnotes.

Key words: fieldnotes; fieldnotes processing; qualitative research.

\section{Wprowadzenie}

Miejsce i status danych empirycznych pochodzących z notatek terenowych jest od kilku dekad przedmiotem dyskusji prowadzonej w środowiskach antropologów i etnografów (Sanjek 1990; Emerson 1995; Lofland 2006; Wal- 
ford 2009 i in.). Niezależnie od reprezentowanego podejścia do pracy terenowej, poglądów na temat sposobu i częstotliwości sporządzania zapisków badacze zgodni są co do tego, że notatki terenowe mają ogromną wartość. Nie tylko pozwalają „zapamiętać” bogactwo szczegółowych informacji dotyczących zdarzeń, procesów, kontekstu, emocji, ale także pozwalają „na utrwalenie bieżącego zapisu wstępnych rozważań analitycznych i proto-koncepcji” (Lofland 2006, s. 167).

W jakościowych eksploracjach edukacyjnych badacze zazwyczaj demonstrują finalny produkt swojej pracy. Często na podstawie lektury raportu trudno rozstrzygnąć czy, a jeśli tak, to w jaki sposób badacz korzystał z notatek terenowych, czy podejmowane decyzje metodologiczne, etyczne były wynikiem pogłębionej refleksji, czy też stanowiły efekt „milczącej wiedzy", z którą badacz wkraczał w teren.

Proces sporządzania notatek, choć wysoce spersonalizowany, na gruncie antropologii i etnografii poddawany jest pewnym próbom porządkowania, kodyfikacji. W literaturze przedmiotu (Jackson 1990; Walford 2009,;Maharaj 2016), spotykamy instrukcje, poradniki, które mają ułatwić, szczególnie młodym badaczom, pracę z notami terenowymi. Sporadycznie jednak badacze ujawniają, w jaki sposób przetwarzają noty terenowe, dzielą się dobrymi praktykami z własnej pracy analitycznej.

Odwołując się do osobistych doświadczeń, prezentowanych w artykule, chciałabym włączyć się do dyskusji na temat strategii przetwarzania not terenowych i roli, jaką odgrywa (auto)refleksyjne myślenie i pisanie, dokumentowane w „prywatnym” świecie notatek terenowych, w odkrywaniu i rozumieniu procesów edukacyjnych.

\section{„Prywatny świat notatek terenowych” - pojęcie i rodzaje}

Chociaż noty terenowe pisane są przez wielu badaczy, to, jak twierdzi Katarzyna Kaniowska, „ścisła definicja fieldnotes nie istnieje, ale przyjęło się zwykle rozumieć przez nie właściwie wszelkie pisane świadectwo, ów pierwszy efekt badań terenowych, względnie "surowy“ tekstualny dowód zetknięcia się badacza z przedmiotem jego obserwacji, doświadczeń, obcowania z ludźmi, obiektami i sytuacjami wybranej kultury. To pierwsze świadectwo ma stanowić bazę danych dla późniejszych generalizacji, syntez czy teoretycznego oglądu" (1995, s. 282).

Praktyka sporządzania notatek terenowych wywodzi się z antropologicznych/etnograficznych procedur rejestrowania danych pochodzących 
z obserwacji uczestniczącej jednak zapiski w terenie sporządzane są przez badaczy wykorzystujących także inne techniki gromadzenia danych - prowadzących wywiady czy realizujących badania w działaniu. Korzysta się z nich wówczas, gdy rozmówca nie wyraża zgody na nagranie lub jako dopełnienie danych, które zostały utrwalone na nośniku elektronicznym. Czasem, jak przekonuje moje doświadczenie badawcze, sporządzenie noty terenowej jest jedynym sposobem „zatrzymania” informacji, do których badacz uzyskał dostęp poza protokołem badania. Ilustruje to poniższy fragment noty terenowej:

Zasadnicza część wywiadu, który nagrałam trwała około godziny. Badana, choć nie wyglądała na speszoną sytuacją wywiadu, była bardzo oficjalna, starannie dobierała, wręcz ważyła słowa, unikała odnoszenia się do swoich osobistych doświadczeń zawodowych. Miałam wrażenie, jakbym słuchała starannie przygotowanego wystąpienia. Kilkakrotnie pomyślałam, że tracę czas. Tuż po wyłączeniu dyktafonu nauczycielka zapytała mnie, czy chciałabym zobaczyć jej teczkę osiągnięć, którą przygotowała na stopień nauczyciela dyplomowanego. Bez entuzjazmu, raczej z konieczności niż ciekawości, zgodziłam się. I wtedy się zaczęło. Stopniowo, przerzucając kolejne karty z opasłego segregatora, przetykanego kolorowymi zakładkami, nauczycielka rozpoczęła bardzo osobistą opowieść o swoich doświadczeniach zawodowych. Dyktafon wyłączony leżał na biurku, dopiero w samochodzie zaczęłam zastanawiać się, co ja mam z tą opowieścią teraz zrobić (NT/K:ND:2)․․

Osobiste zapiski badacza poczynione w toku obserwacji w terenie mają różną treść, objętość, formę, stylistykę. Niektórzy badacze prowadzą bardzo obszerne, wielostronicowe opisy w specjalnych notatnikach, inni piszą na marginesach transkrybowanych wywiadów, luźnych kartkach przypinanych do transkrypcji lub konstruowanych not teoretycznych. Pamiętniki, dzienniki (osobiste i instytucjonalne), zapiski z terenu, prowadzone zgodnie $z$ bardzo zindywidualizowanymi regułami, nie są przygotowywane do przedstawiania zewnętrznemu czytelnikowi, w odróżnieniu od transkrypcji wywiadów, materiałów wizualnych, danych zastanych. Nie mając charakteru publicznego, w swojej pierwotnej formie, są udostępniane niewielkiemu gronu odbiorców, stąd badacze w ich sporządzaniu nie przywiązują większej wagi do staranności gramatycznej, stylistycznej, płynności narracji. Notatki terenowe, w odróżnieniu od innych tekstów pisanych przez badaczy, mają otwarty charakter. Służą nie tylko rejestrowaniu i zapamiętaniu doświad-

1 Oznaczenia przy notach to kody identyfikacyjne stosowane w badaniach np. NTnota terenowa, K - kobieta, ND - nauczyciel dyplomowany, 2 - numer kolejny wywiadu. 
czenia w terenie, ale wielokrotnie przeglądane, przetwarzane, kodowane są źródłem analitycznego namysłu badacza, wyłaniania kategorii i dokonywania uogólnień.

W artykułach poświęconych sposobom prowadzenia notatek terenowych, często kierowanych do młodych badaczy (Walford 2009; Maharaj 2016) podkreśla się, że powinny one być jak najbardziej szczegółową formą dokumentowania pracy terenie. Postulat ten jest jednak trudny do spełnienia. Nie da się, jak słusznie piszą Martyn Hammersley i Paul Atkinson, „zaobserwować i zarejestrować wszystkiego. Trzeba dokonać jakiejś selekcji. Jednak jej zasady zmieniają się w czasie" (1990, s. 185). We wstępnej fazie realizacji projektu zakres zapisków jest bardzo szeroki, jednak w miarę postępu badań następuje identyfikacja problemów, a notatki zaczynają koncentrować się wokół wyłanianych na gorąco kategorii. Ilustruje to zmiana zapisów, jakie sporządziłam przed wyłonieniem w procedurze kodowania kategorii i po nim: wzorce motywacyjne wyboru zawodu nauczycielskiego. Oto fragment noty po przeprowadzonym wywiadzie we wstępnej fazie projektu:

Porządek opowieści był niezwykle chronologiczny i chociaż w pytaniu inicjującym nie pytałam o doświadczenia z dzieciństwa, to swoją opowieść o karierze zawodowej rozpoczęła od długiego, bardzo obszernego opisu doświadczeń biograficznych z tego okresu. Zauważyłam, że ta część narracji sprawiała jej wyraźną przyjemność - była ożywiona, wybuchała śmiechem, gdy szczegółowo wyjaśniała mi, jak już w szkole podstawowej uczyła młodsze rodzeństwo, jak prowadziła zeszyt - dziennik lekcyjny i posługiwała się czerwonym długopisem do sprawdzania zadań i wystawiania ocen. Do wspomnień z dzieciństwa powracała kilkakrotnie, aby przywoływać formułowaną przez jej najbliższe otoczenie opinię, że ma wrodzony talent do bycia nauczycielką (NT/K: ND:4).

Fragment noty odnoszący się do obserwowanego analogicznego doświadczenia zawodowego innej nauczycielki po wyłonieniu kategorii: wzorce motywacyjne:

Narracja „o powołaniu” w tej samej bajkowej konwencji. Pojawiła się, tak jak w we wcześniejszych wywiadach, niezależnie od sposobu sformułowania pytania inicjującego (NT/K: NM:7).

Dokumentowanie doświadczeń w terenie, choć często bardzo drobiazgowe, nie jest obiektywnym zapisem/odzwierciedleniem badanej rzeczywistości. Każdy badacz świadomie lub nie skupia uwagę wokół tych obiektów, 
zdarzeń, osób, wypowiedzi, zachowań, którym nadaje znaczenie. Dlatego not terenowych nie można traktować jako obiektywnych danych, ale jak podkreśla Kaniowska, są one „autorskim zapisem poprzedzonym czyimś wyborem treści uznanych za konieczne lub znaczące i czynionym w czyimś indywidualnym, kulturowo skodyfikowanym języku. Zapis ten pośredniczy więc pomiędzy rzeczywistością, a jej odbiorcą; jest zatem tej rzeczywistości interpretacją" (1995, s. 282). Tak rozumiany proces interpretacji obserwowanych/zapamiętanych zdarzeń w terenie jest wypadkową szeregu czynników zarówno osobistych (wrażliwość, spostrzegawczość, otwartość badacza $\mathrm{i}$ in.), jak i wynikających ze specyfiki pracy i pozycji badacza w terenie. James Clifford (1990), dokonując rozróżnienia pojęcia opisu, jako terminu używanego dla oznaczenia pewnej konkretnej czynności podejmowanej przez badaczy, wyróżnia trzy typy not terenowych: inskrypcję, transkrypcję i deskrypcję.

Inskrypcja polega na przepisywaniu, notowaniu własnych obserwacji i wrażeń oraz wypowiedzi informatorów. To próba szczegółowego opisu, uchwycenia jak największej liczby obrazowych szczegółów, na podstawie których mogą powstawać generalizacje. Ilustruje to poniższy fragment noty sporządzonej po przeprowadzeniu wywiadu:

Narratorka nie potrzebowała zachęty do rozpoczęcia opowieści. Sama nawiązała do naszej pierwszej rozmowy telefonicznej i zakreśliła obszar, o którym zamierza mówić. Mimo to miałam wrażenie, że ta sytuacja ją nieco krępuje (kilkakrotnie zmieniała pozycję ciała, spoglądała na położony na biurku dyktafon, pokasływała). Opisy zdarzeń były bardzo szczegółowe, chyba dlatego gubiła się pomiędzy wątkami, a ja razem $\mathrm{z}$ nią. $\mathrm{W}$ wielu sytuacjach odwoływała się do mojej wiedzy o szkole i moich zawodowych doświadczeń - „jak pani sama rozumie, przecież u was jest tak samo, co ja tam będę pani tłumaczyć, szkoła jest, jaka jest”. Odsłuchując nagranie, zauważyłam, że te frazy wypowiadała „konspiracyjnym szeptem”, ot taka nić branżowego porozumienia (NT/ND:K:21).

Transkrypcja polega na dokonaniu jak najwierniejszego przekładu badanej rzeczywistości, która umyka bezpośredniej obserwacji. To elementy kontekstu, kultury, w jakich zanurzeni są uczestnicy badań. Powstały w procesie transkrypcji, a następnie translacji tekst notatki jest efektem dyskursu, a nie odwzorowaniem badanej rzeczywistości. Tekstem, w którym badacz stara dokonać się jak najwierniejszego odwzorowania przekładu, aby badaną rzeczywistość uczynić zrozumiałą dla siebie i zewnętrznego czytelnika. Ilustruje to poniższy zapis: 
Progres - na początku sądziłam, że to typowy przejaw nauczycielskiej nowomowy. I dopiero dzisiaj, jak badana detalicznie objaśniała logikę procedury mierzenia przyrostu kompetencji uczniów w szkole, złapałam, że to słowo-klucz odnoszące się do złożonego systemu praktyk skierowanych wyłącznie na zaspokajanie biurokratycznych wymogów/oczekiwań. Świetnie to spuentowała: „progres musi być, bo przecież dzieciak w szkole nie może się cofnąć” (NT/K:ND/32).

Trzecim typem notatek terenowych wyróżnionych przez Clifforda jest deskrypcja, która od wcześniejszych różni się nie tyle treścią, ile formą zapisu. Kaniowska twierdzi wręcz, jest to swoista „konwencja literacka, która pozwala powiązać opinię badacza z relacją informatora [...] To swoiste splecenie informacji i doświadczeń antropologa z informacjami udzielanymi mu przez badanych" (1995, s. 285). Notatki terenowe nie są zatem tylko zbiorem zanotowanych zdarzeń i ich wieloaspektowym objaśnianiem. Są polifoniczne „pełne pogłosów i przywołań cudzych wypowiedzi, nie zorganizowanych jeszcze w dyskurs podporządkowany autorskiej intencji antropologa" (Rakoczy 2014, s.80), któremu stopniowo badacz nadaje spójność i wydobywa ukryte znaczenia. Ilustruje to poniższy fragment pochodzący z noty terenowej po wstępnym opracowaniu:

Wejście w grupę profesjonalną to balansowanie na cienkiej linie sprzecznych oczekiwań. Z jednej strony na młodych, co podkreślali wszyscy nowicjusze, wywierany jest taki rodzaj presji, aby się wykazać - co umie, jaką ma motywację, no i oczywiście czy umie utrzymać dyscyplinę w klasie. Z drugiej nowicjuszom, co dokumentuje się w wypowiedziach także bardziej doświadczonych już nauczycieli, wysyła się czytelne sygnały - nie wychylaj się, znaj swoje miejsce w szeregu. Jak powiedziała to ta młoda nauczycielka „dość szybko zrozumiałam, co oznacza powiedzenie że jak się wchodzi między wrony..." (fragment noty po opracowaniu wstępnym).

Zróżnicowanie doświadczenia badacza w terenie, szerokie spektrum form dokumentowania badanej rzeczywistości, odporność na skodyfikowanie powodują, że określenie statusu not terenowych jako rodzaju pisarstwa naukowego jest bardzo trudne. Być może dlatego badacze nie wykorzystują ich analitycznego potencjału, tak jak danych gromadzonych innymi metodami. Wartość not terenowych zawiera się jednak nie tylko w uwrażliwianiu badacza na zjawiska i procesy zachodzące w sytuacji badania czy rozwijaniu umiejętność obserwowania (nie)codziennych sytuacji. Pisanie not rozwija wrażliwość badacza na dostrzeganie zdarzeń, które z początku niezauważal- 
ne stanowią istotny element rozumienia badanej rzeczywistości, pozwalają także ujawniać „milczącą” wiedzą badacza, z którą wkracza w teren badań, analizować zdarzenia z perspektywy temporalnej i skłaniają do namysłu i dialogu ze sobą samym.

\section{Przetwarzanie i analizowanie not terenowych - potencjał i wybrane problemy}

Praca z notami terenowymi, tak jak i ich sporządzanie, jest wysoce zindywidualizowaną czynnością, otaczaną przez niektórych badaczy aurą tajemniczości. Przyczyn niechęci do ujawniania sposobów ich analizy jest zapewne wiele. Być może jednym z powodów jest wciąż obecna w tradycji środowisk akademickich „depersonalizująca konwencja uprawiania i utrwalania badań w humanistyce" (Kruszelnicki 2012, s. 1), która sprawia, że zapisywanym na gorąco spostrzeżeniom, refleksjom (obarczonym piętnem subiektywizmu), nie przyznaje się statusu wartościowych danych empirycznych. Notom wyznacza się rolę „zewnętrznej pamięci” badacza. Być może zapiski oglądane z pewnej perspektywy czasowej, na kolejnych etapach pracy analitycznej, mogą wydawać się ich autorom naiwne, banalne, niewarte upubliczniania. Być może przyczyną jest po prostu brak znajomości strategii pracy z notami terenowymi.

Nie istnieje jedyna „właściwa” metoda pracy z fieldontes. Robert Emerson (1995) sugeruje, aby zapiski badacza poddawać procedurom analitycznym metodologii teorii ugruntowanej. Jego propozycja wydaje się interesująca, pozwala bowiem zarówno dokonywać komparacji danych w obrębie przypadków, jak i analizować dane pochodzące z wielu źródeł.

Praca z notami, jak pisze Emerson (1995), obejmuje kilka etapów: staranne i dokładne czytanie całości sporządzonych zapisków, kodowanie otwarte, pisanie wstępnych not analitycznych, kodowanie skoncentrowane, integrowanie not analitycznych. Procedury te są opisane w literaturze przedmiotu (Konecki 2000; Charmaz 2009; Glaser, Strauss 2009) wykorzystywane są bowiem przez badaczy w pracy z innymi typami danych empirycznych. Jednak stosowanie ich w konkretnym projekcie badawczym, zawsze rodzi szereg odkryć, trudności, których nie sposób wcześniej przewidzieć. Ze względu na ograniczone ramy opracowania chciałabym wskazać na dwa doświadczenia, w których noty terenowe podczas ich podczas przetwarzania i analizowania pozwoliły przenieść analizę na wyższy poziom. Wybrane przykłady są, jak sądzę, nie tylko dowodem złożoności i skompli- 
kowania pracy badacza jakościowego, ale pokazują równocześnie potencjał analityczny zapisków terenowych.

Dzięki starannej i uważnej lekturze całego korpusu danych zgromadzonych w terenie badacz rozpoczyna proces porządkowania i (re)interpretacji treści zapisków. Umożliwia mu to procedura kodowania, czyli „nadawania segmentom danych etykiety, która jednocześnie kategoryzuje, podsumowuje i wyjaśnia poszczególne dane" (Charmaz 2009, s. 60). Etykietowanie oznacza, że badacz, sięgając do zasobów pojęciowych, w pierwszej kolejności dyscypliny, której jest reprezentantem, stara się jak najlepiej je „dopasować”, oddać sens i znaczenie wyłaniających się z danych kategorii.

Prowadząc analizę i interpretację danych $\mathrm{w}$ projekcie poświęconym problemom socjalizacji zawodowej nauczycieli (Kędzierska 2012), poszukując związków pomiędzy wyłaniającymi się kategoriami i ich własnościami, zauważyłam, że pojęcia immanentnie związane $\mathrm{z}$ aparatem pojęciowym pedeutologii, tj. rozwój i awans zawodowy nauczycieli, „nie pasują” do doświadczeń badanych dokumentujących się w danych empirycznych. Mówiąc inaczej, próbując wykorzystywać kategorię rozwoju zawodowego do objaśniania zmian przebiegu profesjonalnego życia nauczycieli, nie mogłam w polu semantycznym kategorii rozwój „zmieścić” takich zjawisk jak: zastój, regres, nielinearność. Rozwój bowiem, jak trafnie zauważa Dorota Klus-Stańska, jest definiowany „w semantyce ukierunkowanego przyrostu, drogi ku czemuś, co określane jest jako lepsze (bardziej rozwinięte) od stanów poprzedzających" (2016, s. 9 ). Ta wzrostowa atrybucja, jednoznacznie pozytywne konotacje, co podkreśla autorka, zamykają pytania o negatywne skutki zmian, które nazywamy rozwojowymi.

Podobnie niefunkcjonalne, z punktu widzenia wypełniania/nasycania kategorii socjalizacji zawodowej okazało się drugie z kluczowych pojęć pedeutologii - awans zawodowy. Zmagania ze znalezieniem kodu "pasującego” do obserwowanych procesów ilustruje poniższy fragment noty wstępnej:

Awans zawodowy, tak jak i rozwój, jest definiowany wyłącznie w kategoriach wzrostu. Awansu nie można cofnąć. Można nauczyciela pozbawić prawa do wykonywania zawodu, ale nie można „odebrać” stopnia zawodowego. Historie nauczycieli o awansie, jego przygotowywaniu i osiąganiu dokumentują zjawisko pozorności rozwoju kompetencji zawodowych, „papierowych” kompetencji i osiągnięć. Ale ani pojęcie awans, ani rozwój nie wyjaśniają okresowych zastojów czy nawet regresu, który identyfikowałam w narracjach obejmujących trudne sytuacje zawodowe, rodzinne badanych lub po osiągnięciu przez nich kolejnego etapu awansu. Czy nauczyciel nie może przestać się rozwijać? Do jakiej kategorii zaliczyć zatem zjawiska stagnacji, wycofania? Jaki- 
mi pojęciami/kategoriami opisać i wyjaśnić nie tylko linearny ruch w górę, ale także w dół oraz poszarpane drogi zawodowych biografii nauczycieli? (fragment noty wstępnej)

Przetwarzanie i integrowanie zapisków z terenu, co ilustruje fragment noty wstępnej, stało się impulsem do przekroczenia ograniczeń aparatu pojęciowego pedeutologii i poszukiwania w obszarze nauk społecznych takich kategorii, które pozwoliłyby rozwiązać problem nieprzystawalności języka dyscypliny do danych wyłaniających się z analizy. Dzięki ścisłemu opieraniu się na danych oraz syntetyzowaniu kodów wstępnych z wywiadów i not terenowych mogłam do analizy fenomenu pracy i profesjonalizacji zawodu nauczyciela zastosować kategorię kariery zawodowej, bardziej „przystającą do danych", złożoną z własności, które zostały dostrzeżone w toku analizy.

Ważnym etapem pracy badacza jest pisanie tekstu raportu. Pisanie jakościowe to coś więcej niż relacjonowanie. Badacz nie próbuje zacierać granic pomiędzy swoją osobą a badanymi, ale „angażuje się z nimi w dialog i dba o przestrzeń dla polifonii głosów kulturowych" (Kruszelnicki 2012, s. 2). Sytuacja badacza raportującego ustalenia empiryczne przypomina rolę dyrygenta wielogłosowego chóru. Nadając ostateczny kształt dziełu, dążąc do osiągnięcia kształtu utworu zgodnego z jego własną, autorską interpretacją, musi jednocześnie zadbać o wybrzmienie każdego głosu. Choć w utworach polifonicznych są one samodzielne i równoważne, to mają jednak własne linie melodyczne. Pisanie jakościowego raportu wymaga zatem stałego balansowania pomiędzy logiką prezentacji autora a logiką teoretyzowanego doświadczenia badanych. Noty terenowe, jak ilustruje to poniższy przykład, odgrywają niezwykle ważną rolę w usłyszeniu "fałszywych tonów” w kompozycji.

Jednym z ważnych wątków rekonstruowanych w toku pisania raportu cząstkowego dotyczącego socjalizacji zawodowej młodych nauczycieli było zjawisko tzw. progu, czyli trudności przechodzenia nowicjusza ze świata akademii do świata szkoły. Jedną z podstawowych linii argumentacyjnych, którą rozwijałam w raporcie, była dotycząca niskiego poziomu kompetencji młodych nauczycieli będących wynikiem braku selekcji kandydatów do zawodu oraz patologii systemu edukacji nauczycielskiej na poziomie wyższym. Tezę tę uzasadniałam nie tylko odniesieniami do literatury przedmiotu (Kwieciński 2007), badań edukacyjnych, ale także danymi z wywiadów z opiekunami stażu, dyrektorami szkół.

Po napisaniu wstępnej wersji rozdziału powróciłam do danych empirycznych (także zapisków terenowych), aby ugruntować przyjętą linię argu- 
mentacyjną. W trakcie tej pracy „odnalazłam” fragment noty zawierający urywek transkrypcji wywiadu z początkującą nauczycielką opatrzony dość obszernym komentarzem:

$\mathrm{W}$ tej pracy to jest ogromny ładunek stresu, ja jestem często wypalona psychicznie, choć przecież dopiero zaczynam w zawodzie, często słyszę ty tylko kilka godzin pracujesz, ale ja po tych czterech godzinach to często wychodzę taka, jakby mnie ktoś walcem rozjechał, bo to jest jednak cały czas napięcie, żeby siedzieli w ławkach, tak żeby zdążyć ich odpytać, wprowadzić nowy temat, żeby jeszcze było cicho i coś w głowie zostało, zdążyć wypełnić dziennik, a oni chcą, aby iść $z$ nimi do kina i taką całodniową też, a przecież ten awans, to może wziąć $\mathrm{z}$ klasą jeszcze udział w jakimś konkursie to to wszystko nie jest takie proste (K:NK:12).

oraz komentarz zapisany w nocie:

Nabywanie i doskonalenie umiejętności zawodowych wymaga czasu. A jednak od młodych nauczycieli (choć awans zakłada istnienie różnic w poziomie kompetencji) oczekuje się wykonywania dokładnie tych samych zadań (organizacyjnych, dydaktycznych, wychowawczych) jak od doświadczonych nauczycieli. Jeśli tak, to na ich tle, nowicjusz zawsze wypadnie blado. Nie można uczyć się i nie popełniać błędów. Dlaczego muszą być rzuceni na od razu głęboką wodę, a nie stopniowo wrastać w zadania profesjonalne? (NT/K: NK:12)

Dostrzeżenie tego fragmentu, uczynienie perspektywy początkującej nauczycielki „widzialną” w analizie nie zmieniły radykalnie toku argumentacji dotyczącej problemów kształcenia nauczycieli przedstawionego w raporcie. Jednak włączenie jej perspektywy jako dopełniającej wielogłosową narrację pozwoliło zadać pytania o przebieg i organizację procesu adaptacji młodych nauczycieli. Zapis w nocie, który „umknął” w czasie pisania wstępnej wersji raportu, przeniósł w rezultacie analizę na wyższy poziom.

\section{Konkluzja}

Pisanie i przetwarzanie not terenowych jest, jak starałam się wykazać, ważną częścią pracy badacza jakościowego. I choć osobiste zapiski w formie dzienników, pamiętników, notatek nie stają się zazwyczaj publicznymi dokumentami, to jednak znaczna ich część trafia w finale do raportu końcowego.

Status not terenowych nie jest jednoznacznie określony. W badaniach edukacyjnych danym $\mathrm{z}$ fieldnotes nie nadaje się rangi równej danym pocho- 
dzącym bezpośrednio z pracy w terenie (wywiady, obserwacja uczestnicząca i in.) Przypisuje się im przede wszystkim funkcję „nośnika pamięci podręcznej" badacza, rzadziej informacyjną, pomijając zupełnie fakt, że zapiski badacza to znakomity materiał służący budowaniu wiedzy o świecie społecznym, a przetworzony, tak jak inne dane, staje się "podstawą analizy i wysuwanych przez badacza twierdzeń" (Lofland 2009, s. 171) .

Dlatego problemy gromadzenia i przetwarzania tak specyficznego rodzaju danych empirycznych nie powinny być skrywane za kurtyną „prywatności”, ale winny stawać się źródłem (indywidualnego i grupowego) namysłu oraz przedmiotem treningu umiejętności warsztatowych badacza.

\section{Bibliografia}

Charmaz K. (2009), Teoria ugruntowana. Praktyczny przewodnik po analizie jakościowej, Wyd. Naukowe PWN, Warszawa.

Clifford J. (1990), Notes on (field)notes, [w:] Sanjek R. (red.), Fieldnotes. The Makings of Antropology, Cornell University Press, Ithaca, s. 47-70

Emerson R. (1995), Processing Fieldnotes: Coding and Memoing, [w:] Emerson R., Fretz R., Shaw L. (red.), Writing ethnographic fieldnotes, Chicago: The University of Chicago Press, s. 142-168.

Glaser B. G., Strauss A. L. (2009), Odkrywanie teorii ugruntowanej, Zakład Wydawniczy NOMOS, Kraków.

Hammersley M., Atkinson P. (1995), Metody badań terenowych, Wyd. Zys i S-ka, Poznań.

Jackson J .E. (1990), „I am fieldnote”: Fieldnotes as a Symbol of Professional Identity, [w:] Sanjek R.(red.), Fieldnotes. The Makings of Antropology, Cornell University Press, Ithaca, s. 4-33.

Kaniowska K. (1995), Czy trudno jest być dzisiaj antropologiem?, „Lud”, t. 78, s. 279-291.

Kędzierska H. (2012), Kariery zawodowe nauczycieli. Konteksty-wzory-pola dyskursu, Wyd. Adam Marszałek, Toruń.

Kędzierska H. (2015), Novice Teachers: The Process of "Anchoring" in the Teaching Profession, „Forum Oświatowe”, nr 2, s. 59-73.

Klus-Stańska D. (2016), Odwrót od rozwoju: kontrowersyjna czy obiecująca zmiana paradygmatu wczesnej edukacji, „Studia Edukacyjne”, nr 38, s. 7-20.

Kwieciński Z. (2007), Między patosem a dekadencją. Studia i szkice socjopedagogiczne, Wyd. Naukowe DSWE TWP ,Wrocław.

Lofland J., Snow, D. A., Anderson L., Lofland L. H. (2009), Analiza układów społecznych. Przewodnik metodologiczny po badaniach jakościowych, Wyd. Naukowe SCHOLAR, Warszawa. 
Maharaj N. (2016), Using field notes to facilitate critical reflection, „Reflective Practice", vol. 17 no. 2, s. 114-124.

Rakoczy M. (2014), „Pisanie” kultury a notatki terenowe - przypadek Bronisława Malinowskiego, „Zeszyty Etnologii Wrocławskiej”, nr 2(21), s. 75-94.

Walford G. (2009), The practice of writing ethnographic field notes, „Etnography and Education" vol. 4, no. 2, s. 117-130.

\section{Neografia}

Kruszelnicki W. (2012), Hermeneutyczne kierunki refleksji nad osoba badacza w terenie, „Kultura i Historia”, nr 21, http://www.kulturaihistoria.umcs.lublin.pl/ archives/35, dostęp: 15.12.2016.

Soroko E. (2009), Raportowanie badań jakościowych i ilościowych. Ukryte podobieństwa i wyraźne różnice, http://www.staff.amu.edu.pl/ soroko/_uploads/2008/03/jakosciowe-i-ilosciowe_soroko.pdf, dostęp: 15.12.2016. 